\title{
BEST PRACTISE PEMANFAATAN LINGKUNGAN SEKOLAH LITERAT DAN MEDIA PEMBELAJARAN LITERASI UNTUK MENUMBUHKAN MINAT BACA SISWA KELAS AWAL
}

\author{
SITI AMINAH \\ MI Muhammadiyah 01 Watukebo Jember \\ Email : siti1283aminah@gmail.com
}

\begin{abstract}
ABSTRAK
Kegiatan membaca sangat penting dikelas awal. Di kelas awal siswa BELAJAR MEMBACA, sedangkan siswa kelas tinggi MEMBACA UNTUK BELAJAR. Ketika siswa terkendala membaca di kelas awal, dia akan selalu tertinggal di jenjang berikutnya. Membaca adalah ketrampilan yang harus diajarkan, tidak bisa sendiri. Mengajarkan membaca perlu strategi dan pendekatan kreatif dan inovatif agar siswa mempunyai minat baca, terdorong untuk memperhatikan, merasa tertarik dan senang terhadap aktivitas membaca, sehingga malakukan aktivitas membaca dengan kemauanya sendiri. Best Practise ini mengkaji cara sekolah menggunakan strategi dan pendekatan kreatif dengan menciptakan lingkungan sekolah yang literat, indah, nyaman dan ramah, serta perlengkapan/media yang menarik, aktivitas yang menyenangkan memotivasi membaca siswa. Lingkungan sekolah dan kelas yang kaya dengan media kebahasaan dan cetakan serta sudut baca, media pembelajaran kreatif inovatif literasi dengan tutup botol, bigbook, dan tabel interaktif berupa jurnal literasi dan bintang baca. Tujuan dibuatnya best practise ini adalah mendeskripsikan pengalaman penulis dalam menciptakan lingkungan sekolah literat dan media pembelajaran literasi untuk menumbuhkan minat baca. Harapan yang ingin dicapai, semoga kegiatan membaca menjadi aktivitas yang sangat menyenangkan bagi anak, terutama dikelas pemula. Membiasakan membaca dikelas awal/pemula bisa menjadi pembiasaan saat ia dewasa.
\end{abstract}

Kata Kunci: Sekolah Literat, Media Pembelajaran literasi, Minat Baca.

\section{PENDAHULUAN}

Kelas awal (kelas rendah) yaitu kelas 1, 2 dan 3 jenjang pendidikan Sekolah Dasar (SD) atau Madrasah Ibtidaiyah (MI). Siswa kelas awal adalah anak yang belajar ditingkatan kelompok kelas 1, 2 dan 3. Usia siswa pada kelompok kelas rendah yaitu 6 atau 7 tahun sampai 8 atau 9 tahun. Siswa yang berada pada kelompok ini termasuk dalam rentangan anak usia dini. Masa usia dini ini merupakan masa yang pendek tetapi sangat penting bagi kehidupan seseorang. Oleh karena itu, pada masa ini seluruh potensi yang dimiliki anak perlu didorong sehingga akan berkembang secara optimal. Pihak pendorong pengembangan potensi anak adalah keluarga, sekolah dan lingkungan masyarakat.

Pengembangan potensi anak dapat dilakukan diantaranya dengan mengembangkan budaya membaca. Membaca adalah upaya aktif pada pembaca untuk memahami pesan seorang penulis.( Dwi Puji Astuti,2013). Menurut Mildred \& Hamman membaca adalah suatu proses penglihatan dan tanggapan, sebagai proses membaca bergantung pada kemampuan melihat simbol-simbol. Manfaat membaca bagi anak untuk melatih konsentrasi, mengembangkan imajinasi dan kreativitas serta membangun konsep dan membuat analisa. Biasakan diri dulu anak suka baca adalah pendekatan dasar untuk menumbuhkan literasi baca. Lingkungan baca dan media yang menyenangkan serta bersifat menghibur. Kemudian dilanjutkan sampai langkah-langkah berikutnya anak terbiasa membaca buku level tinggi.

Lingkungan sekolah dan kelas Literat adalah lingkungan sekolah dan kelas yang kaya dengan media kebahasaan dan cetakan. Lingkungan yang literat diharapkan dapat menumbuhkan motivasi siswa dalam belajar literasi (Hermawan, 2013). Motivasi merupakan kemauan seseorang untuk melakukan sesuatu. Motivasi merupakan bagian dalam seseorang yang menyebabkan untuk melakukan tindakan tertentu dengan cara tertentu pula. Apabila siswa 
dimotivasi dengan pengalaman yang bermakna dengan maksud tertentu, maka siswa akan memiliki kesiapan yang baik dan prima belajar. Di dalam konsep kelas yang terpusat pada literasi, motivasi sangat diperlakukan untuk menciptakan pengalaman yang bermakna, menumbuhkan sikap positif pada membaca dan menulis, serta menarik perhatian dan keantusiasan untuk mencapai yang lebih tinggi.

Minta baca pun terbentuk dari motivasi dari sikap positif tersebut. Minat membaca adalah sikap positif dan adanya rasa keterikatan dalam diri anak terhadap aktivitas membaca dan tertarik terhadap buku bacaan (Santoso, 2011).

Tujuan dibuatnya best practise ini adalah mendeskripsikan pengalaman penulis: 1 . Menciptakan lingkungan sekolah dan kelas literat yang menarik dan menyenangkan dengan sudut baca agar anak tertarik dan familier akan lingkungan literasi. 2. Membuat media kreatif, inovatif, fleksibel, mudah dan sederhana dengan media pembelajaran tutup botol dan big book untuk memberikan inovasi kegiatan baca yang menyenangkan/menghibur/tidak membosankan dan kreatif. 3. Membuat tabel interaktif berupa bintang baca/bintang literasi yang variatif mampu memotivasi siswa rajin dan terbiasa membaca. Terbiasa membaca di usia dini diharapkan menjadi terbiasa membaca saat dewasa.

\section{METODE PELAKSANAAN}

Tahapan-tahapan best practise menumbuhkan minat baca terdiri dari: 1. Menciptakan lingkungan sekolah dan kelas literat yang menarik dan menyenangkan dengan sudut baca. 2 . Membuat media kreatif inovatif fleksibel, mudah dan sederhana dengan media pembelajaran tutup botol, bigbook dan buku zigzag. 3. Membuat tabel interaktif berupa bintang baca/bintang literasi yang variatif.

Pelaksanaan kegiatan dilakukan di MI Muhammadiyah 01 Watukebo-Jember-Jawa Timur. Waktu pelaksanaan kegiatan mulai bulan Mei sampai Desember 2019. Implementasi Pembuatan kelas literat kelas awal di MI muhammadiyah 01 Watukebo melibatkan guru, paguyuban dan siswa. Hasilnya antara lain : 1.Tulisan di dalam kelas, berupa tulisan-tuliasan, alfabet/abjad didinding, nama hari, nama bulan, nama benda di dalam kelas, jadwal kegiatan kelas, slogan dll. 2. Tabel Interaktif/Tabel Komunikasi dua arah, berupa jurnal baca, jurnal tahfidz, tabel iqro, jurnal prestasi dll. 3. Tulisan Guru dan Siswa, berupa tulisan siswa, tulisan guru, karya siswa, karya guru dll. 4. Pajangan Karya Siswa, berupa pajangan karya siswa, karya guru baik 2 dimensi maupun 3 dimensi, Seperti lukisan, bunga dll. 4. Perpustakaan Kelas/Sudut Baca, berupa tempat baca dan rak baca yang berisi buku-buku cerita atau bahan cetakan lainnya, seperti koran atau majalahanak-anak yang disesuaikan minat, usia, dan kemampuan membaca. Sudut baca digunakan untuk tenpat membaca, menulis, diskusi, dan pajangan merupakan sarana untuk berkarya. Jadi disediakan alat tulis untuk berkarya.

Langkah pembuatan sudut baca: 1. Pilih sudut kelas yamg digunakan untuk tempat baca. 2. Sediakan pada sudut baca rak buku, buku bacaan dan alat tulis. 3. Siapkan tikar atau alas untuk membaca. 4. Tempel sudut baca dengan berbagai media kebahasaan, cetakan dan tulisan. 5. Hias semenarik mungkin area sudut baca. Membuat media kreatif inovatif fleksibel, mudah dan sederhana dengan media pembelajaran tutup botol diawali dengan menyiapkan alat dan bahan; tutup botol, lem, gunting, kertas huruf/suku kata/kata. Cara pembuatannya: Gunting kertas huruf/suku kata/kata dan tempel pada permukaan tutup botol.

Membuat media bigbook, diawali dengan menyiapkan alat dan bahan; kertas gambar A3, spidol, krayon/pensil warna. Cara pembuatannya: 1. Menentukan judul dan topik cerita. 2 . Mengembangkan topik menjadi sub bagian cerita dengan menggunakan peta pikiran 3 . Mengembangkannya menjadi cerita utuh yang terdiri dari beberapa kalimat. 4. Menuliskan pada kertas A3. 5. Bigbook dicetak. 6. Guru membuat daftar pertanyaan isi bigbook sebelum menggunakan bigbook. 7. Membuat tabel interaktif berupa bintang baca/bintang literasi yang variatif, ada yang berbentuk tabel dan pohon prestasi. 


\section{HASIL DAN PEMBAHASAN}

Berikut ini adalah hasil-hasil best practise:

\section{Lingkungan sekolah/kelas Literat}

Lingkungan sekolah dan kelas Literat adalah lingkungan sekolah dan kelas yang kaya dengan media kebahasaan dan cetakan. Lingkungan yang literat diharapkan dapat menumbuhkan motivasi siswa dalam belajar literasi. (Hermawan, 2013) Motivasi merupakan kemauan seseorang untuk melakukan sesuatu. Motivasi merupakan bagian dalam seseorang yang menyebabkan untuk melakukan tindakan tertentu dengan cara tertentu pula. Apabila siswa dimotivasi dengan pengalaman yang bermakna dengan maksud tertentu, maka siswa akan memiliki kesiapan yang baik dan prima belajar. Di dalam konsep kelas yang terpusat pada literasi, motivasi sangat diperlakukan untuk menciptakan pengalaman yang bermakna, menumbuhkan sikap positif pada membaca dan menulis, serta menarik perhatian dan keantusiasan untuk mencapai yang lebih tinggi.

Hal-hal yang dapat dikembangkan didalam kelas literat antara lain :

\section{1) Tulisan di dalam kelas}

Kelas yang literat dapat ditunjukkan dengan banyaknya tulisan di dalam kelas. Tulisan ini berupa nama siswa, alfabet/abjad di dinding, nama hari, nama bulan, nama benda di dalam kelas, jadwal kegiatan kelas dll. Semakin banyak tulisan yang diperkenalkan maka semakin banyak informasi yang didapat siswa dalam belajar literasi. Pengalaman dengan huruf dan kata yang diperoleh akan membantu mereka dalam kegiatan membaca dan menulis. Contonya : nama siswa yang ditempelkan pada dinding baca. Tulisan yang diserap otak sebagai informasi dan akan menempel dalam ingatan siswa karena mereka melihatnya setiap hari. Dengan cara ini tanpa sadar, mereka akan banyak mengenal huruf atau tulisan tanpa harus menghafal.

\section{2) Tulisan Guru dan Siswa}

Siswa kelas sangat menyenangi pembicaraan yang berkaitan dengan diri mereka, hasil karya yang digunakan sebagai bahan diskusi akan memotivasi mereka untuk kegiatan belajar dengan semangat. Contoh : hasil dari tulisan siswa di papan tulis lalu diceritakan sendiri oleh siswa tersebut didepan kelas. Dengan kegiatan ini melatih siswa untuk mengembangkan keterampilan menulis dan berbicara. Contoh media lain yang dapat di gunakan untuk mengembangkan dua keterampilan tersebut adalah jawaban siswa yang ditulis guru, cerita yang dihasilkan bersama dll. Contoh tulisan guru dan siswa.

\section{3) Pajangan Karya Siswa}

Setiap karya siswa yang dipajang memberi motivasi kepada siswa untuk terus berkarya menghasilkan karya yang lebih baik lagi. Pajangan perlu diganti apabila topik yang dibahas sudah selesai.

\section{4) Perpustakaan kelas/Pojok Baca}

Perpustakaan kelas dibuat dengan tujuan menunjang kegiatan membaca mandiri. Isinya berupa buku-buku cerita atau bahan cetakan lainnya, seperti koran atau majalahanak-anak yang disesuaikan minat, usia, dan kemampuan membaca. Perpustakaan kelas sebaiknya diatur agar tempatnya menyenangkan sehingga siswa tergugah untuk membaca. Pembiasaan membaca dapat dilakukan sebagai kebutuhan. Seperti : Membaca setelah menyelaikan tugas.

Tenpat membaca, menulis, diskusi, dan pajangan merupakan sarana untuk berkarya. Jadi alangkah baiknya jika didalam kelas ada pojok baca untuk tempat membaca dan pojok menulis yang dilengkapi dengan alat tulis untuk memberikan kesempatan kepada siswa menuangkan idenya lewat tulisan.

\section{5) Sikap Guru}

Guru yang antusias menyikapi aktivitas membaca dan menulis siswa secara positif sangat mempengaruhi keberhasilan siswa. Demikian juga dengan guru yang percaya bahwa siswanya dapat belajar dan berbagi pengalaman dengan temannya. Sikap guru hendaknya menummbuhkan menumbuhkan harapan bagi siswa untuk mencapai keberhasilan

\section{6) Partisipasi Orang tua}


Guru yang mengkomunikasikan pekerjaan siswa kepada orang tuanya termasuk guru yang mempertahankan tingkat motivasi siswa yang tinggi untuk belajar. Melalui komunikasi seperti itu orang tua akan mengetahui pentingnya dukungan mereka terhadap keberhasilan siswa dalam membaca dan menulis. Orang tua juga dapat berperan sebagai bagian dari pembaca yang membantu pemahaman membaca putra - putrinya ketika dirumah. Alternatif lain untuk mengajak orang tua berpartisipasi adalah dengan meminta mereka membelikan buku baca dan membuat program baca dirumah.Tujuan ini adalah selain orang tua merasa terlibat dalam program literasi, para siswa akan merasa didukung oleh orang tuanya.

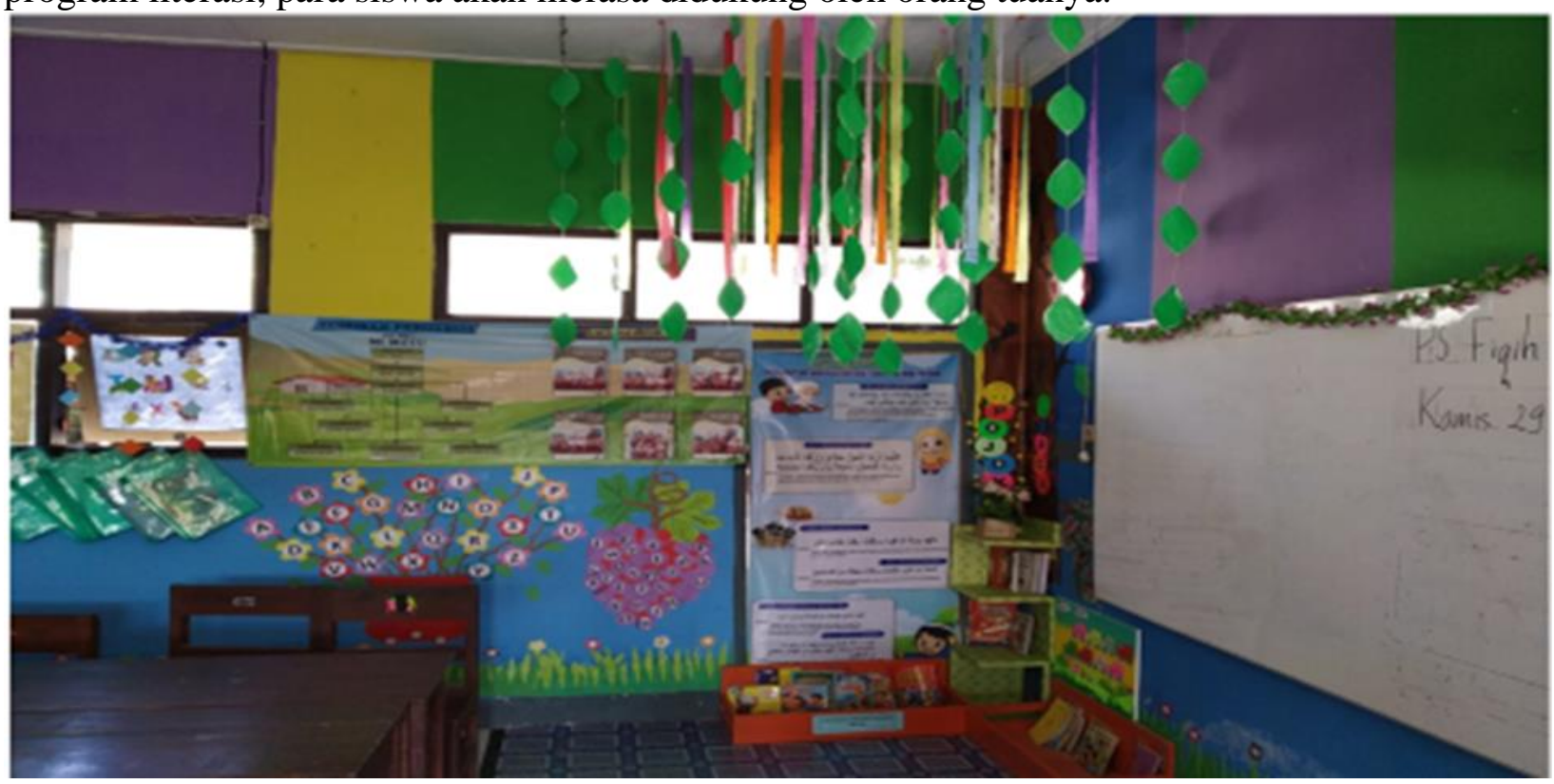

Gambar 1. Kelas literat dengan sudut baca.

Berikut ini perubahan positif dari Kelas Literat/Sudut Baca:

\begin{tabular}{|c|c|}
\hline Sebelum & Sesudah \\
\hline $\begin{array}{l}\text { a. Siswa malas membaca karena kurang } \\
\text { tersedianya tempat dan bahan bacaan. } \\
\text { b. Siswa tidak tertarik semua tentang buku, } \\
\text { memiliki ataupun membeli buku. } \\
\text { c. Minat baca siswa rendah, terekap dalam } \\
\text { Read Record (RR) } \\
\text { d. Tidak terdapat sudut baca/pojok baca } \\
\text { dikelas. } \\
\text { e. Kelas terlihat lengang/jarang pajangan } \\
\text { dan sepi tulisan. } \\
\text { f. Koleksi buku hanya terdapat di } \\
\text { perpustakaan sekolah. }\end{array}$ & $\begin{array}{l}\text { a. Siswa gemar membaca karena } \\
\text { tersedianya tempat dan bahan bacaan di } \\
\text { kelas. } \\
\text { b. Siswa familier dengan buku. Termotivasi } \\
\text { untuk membeli buku. } \\
\text { c. Minat baca siswa tinggi, terekap dalam } \\
\text { Read Record (RR) } \\
\text { d. Terdapat sudut baca/pojok baca. Pojok } \\
\text { baca dapat digunakan sebagai tempat } \\
\text { kegiatan membaca, dan kegiatan } \\
\text { pembelajaran } \\
\text { e. Kelas terlihat indah, menarik, dan } \\
\text { menyenangkan. Banyak pajangan dan } \\
\text { tulisan. } \\
\text { f. Bertambahnya koleksi buku } \\
\text { g. Menjadi juara madrasah literat }\end{array}$ \\
\hline
\end{tabular}




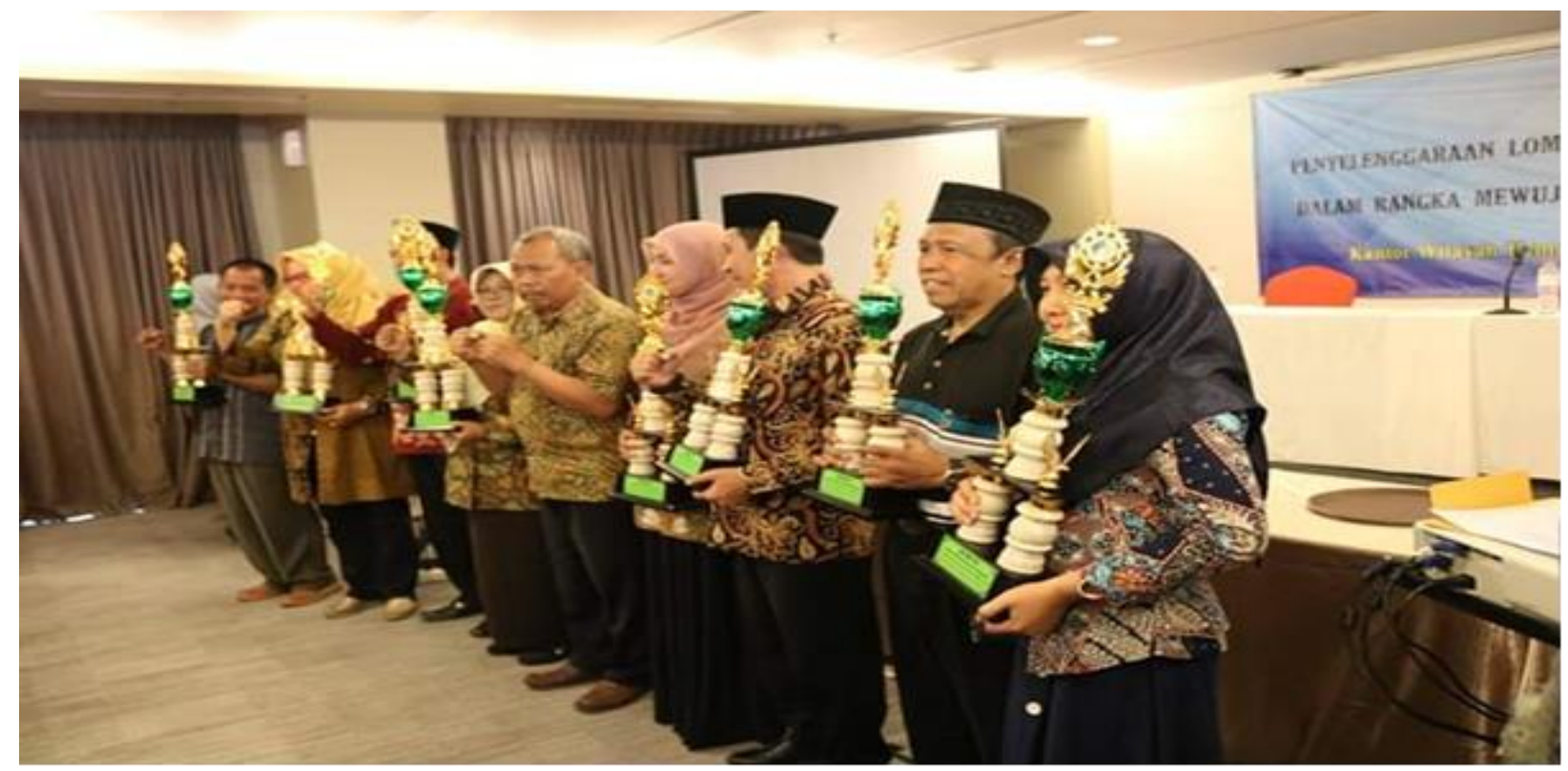

Gambar 2. Juara Madrasah Literat Tingkat Jawa Timur.

\section{Media Pembelajaran Tutup Botol.}

Media pembelajarn merupakan bagian tak terpisahkan dari kegiatan pembelajaran disekolah. Pemanfaatan media pembelajaran juga merupakan upaya kreatif dan sistematis untuk menciptakan pengalaman yang dapat membantu proses belajar siswa. Hal ini dikarenakan media berperan sebagai alat perangsang belajar dan dapat menumbuhkan motivasi belajar sehingga murid tidak mudah bosan dalam mengikuti proses belajar mengajar.

Menurut pandangan Tim Applied Approach Peningkatan Rancangan Pengajaran Universitas Brawijaya (1993) beberapa langkah dalam memilih media sesuai dengan situasi dan kondisi : 1. Biayanya murah, baik saat pembelian, dalam pengoperasian, dan pemeliharaan. 2. Kesesuaian dengan metode pengajaran yang digunakan. 3. Kesesuaian dengan karakteristik peserta didik. 4. Pertimbangan praktis, kemudahan, keamanan, kesesuaian dengan fasilitas yang ada, keawetan dan kemudahan pemeliharaan. 5. Ketersediaan media.

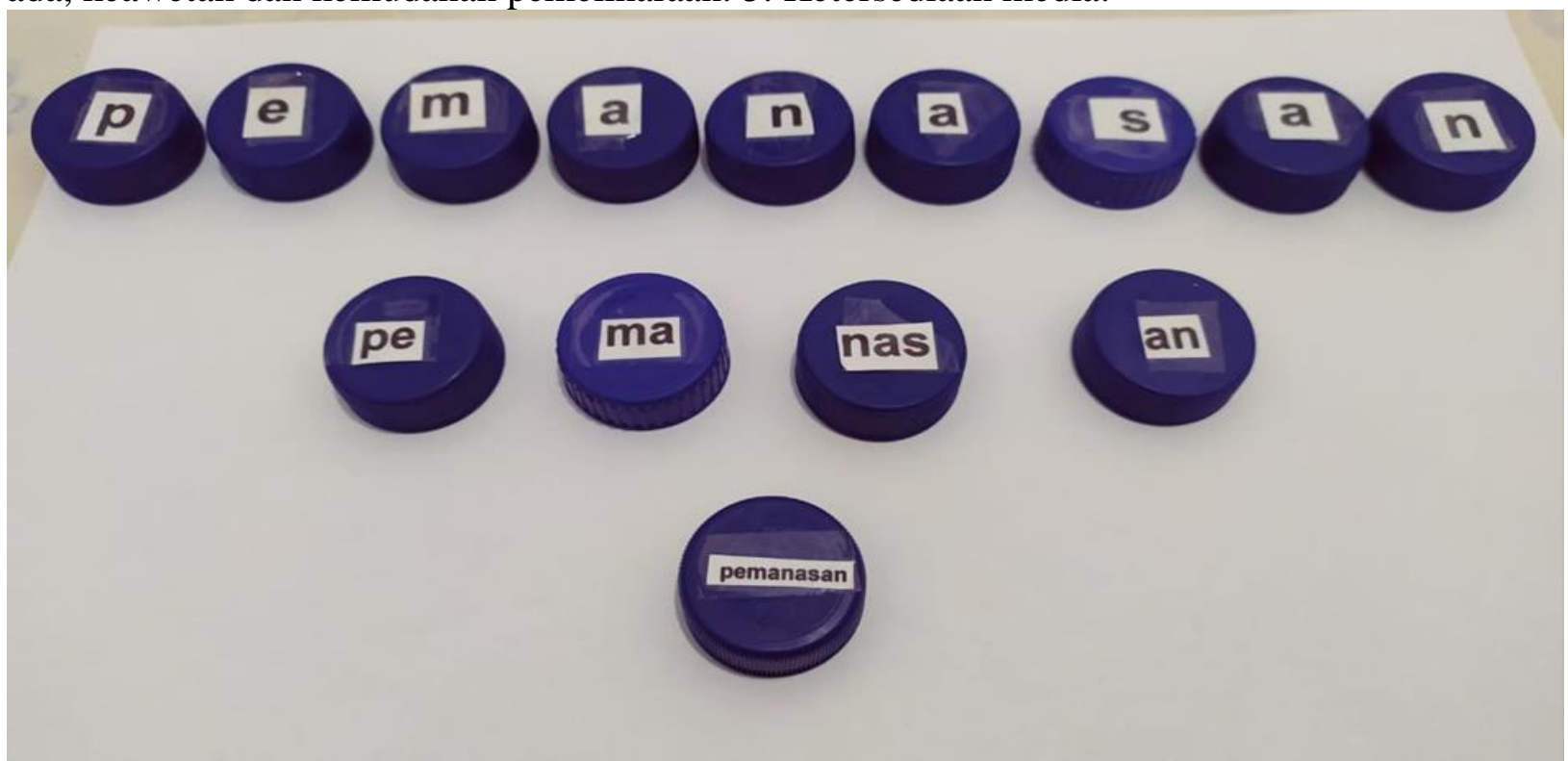

Gambar 3. Contoh Media Pembelajaran Tutup Botol.

Tutup botol kita jadikan media keterampilan membaca huruf, suku kata,kata dan membuat kalimat. Ketersediaan bahan yang mudah didapat, mendorong kita untuk memilih 
media ini. Siswa mendapatkan bahan dari tutup bekas teh coca cola yang mereka beli dikantin sekolah.

Media ini dibuat guru dan siswa. Siswa membawa bahan dan alat.Guru membimbing pembuatannya. Media ini tergolong jenis media yang mudah dibuat, murah, dan menarik untuk permainan.

Cara bermain :

1. Siswa duduk perpasangan

2. Seorang berperan menjadi guru dan yang seorang lagi menjadi siswa

3. Siswa yang berperan menjadi guru menyusun botol secara berderet, sedangkan siswa yang menjadi siswa membaca huruf/suku kata/kata.

4. Siswa berganti peran.

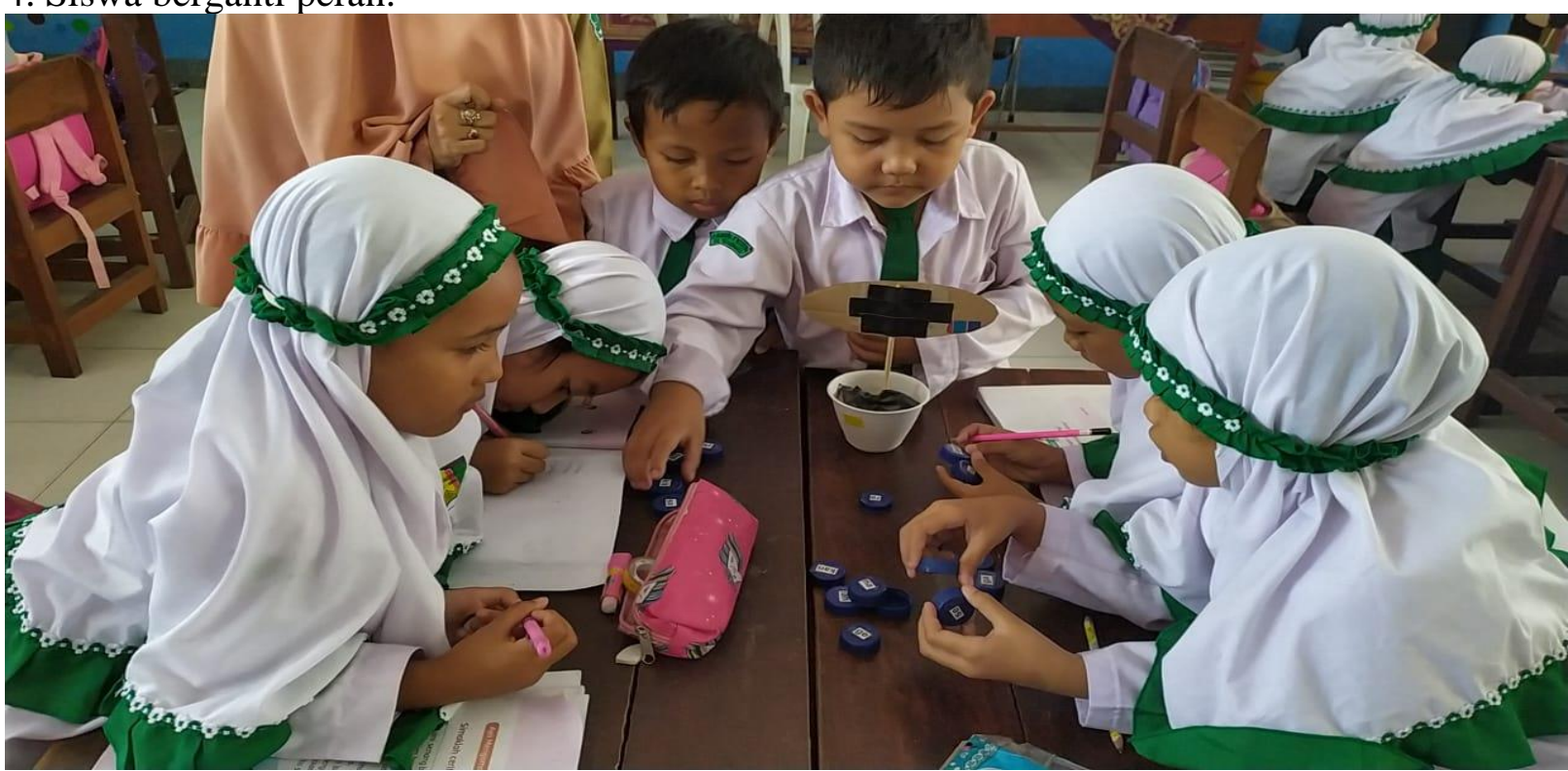

Gambar 4. Siswa Antusias Membaca Dengan Media Pembelajaran Tutup Botol.

Berikut ini perubahan positif media pembelajaran tutup botol:

\begin{tabular}{|l|ll|}
\hline \multicolumn{1}{|c|}{ Sebelum } & \multicolumn{1}{c|}{ Sesudah } \\
\hline a. $\begin{array}{l}\text { Siswa kurang minat membaca karena } \\
\text { media baca monoton, kurang } \\
\text { menarik/cuma buku. }\end{array}$ & a. $\begin{array}{l}\text { Siswa antusias membaca dari media. } \\
\text { b. } \begin{array}{l}\text { Siswa merasakan kegiatan membaca } \\
\text { adalah kegiatan yang membosankan. }\end{array}\end{array}$ & $\begin{array}{l}\text { Siswalah kegiatan yang menyenangkan. } \\
\text { Kegiatan membaca dikemas dalam } \\
\text { bentuk permainan. }\end{array}$ \\
c. $\begin{array}{l}\text { Media yang ada biaya mahal harus } \\
\text { membeli. }\end{array}$ & c. $\begin{array}{l}\text { Bahan media murah. Memanfaatkan } \\
\text { barang bekas yang banyak tersedia di } \\
\text { kantin sekolah. }\end{array}$ \\
& & \\
\hline
\end{tabular}

\section{Media Pembelajaran Bigbook.}

Buku Besar (Big Book) adalah buku bacaan yang memiliki ukuran, tulisan, dan gambar yang besar. Ukuran Big Book harus mempertimbangkan segi keterbacaan seluruh siswa di kelas.

Big Book dapat digunakan di kelas awal karena memiliki karakteristik yang sesuai dengan kebutuhan siswa. Guru dapat memilih Big Book yang isi cerita dan topiknya sesuai dengan minat siswa atau sesuai dengan tema pelajaran. Bahkan, guru dapat membuat sendiri Big Book sesuai dengan kebutuhan. 
Big Book digunakan oleh guru saat ia sedang melakukan pemodelan membaca atau membaca bersama. Jenis buku ini akan diminati siswa karena tampilannya menarik perhatian mereka.

Dengan ukurannya yang besar dan gambar yang menarik, Big Book memiliki beberapa keistimewaan, di antaranya adalah berikut: a. Memberikan kesempatan kepada siswa untuk terlibat dalam kegiatan membaca dengan cara yang menarik. b. Memungkinkan semua siswa melihat tulisan yang sama ketika guru membaca tulisan tersebut. c. Memungkinkan siswa secara bersama-sama memberi memahami tulisan yang ada dalam Big Book. d. Memberikan kesempatan kepada siswa yang lambat membaca untuk mengenali tulisan dengan bantuan guru dan teman-teman lainnya. e. Disukai siswa, termasuk siswa yang terlambat membaca.

Mengingat pentingnya Big Book bagi siswa kelas awal, sebaiknya guru memproduksi beberapa buku tersebut untuk persiapan satu tahun ajaran.

Pembuatan bigbook di MI Muhammadiyah 01 Watukebo dimulai dari kelas awal untuk keterampilan membaca terbimbing. Media ini sangat menarik, kemudian kita akan kembangkan untuk kelas atas.

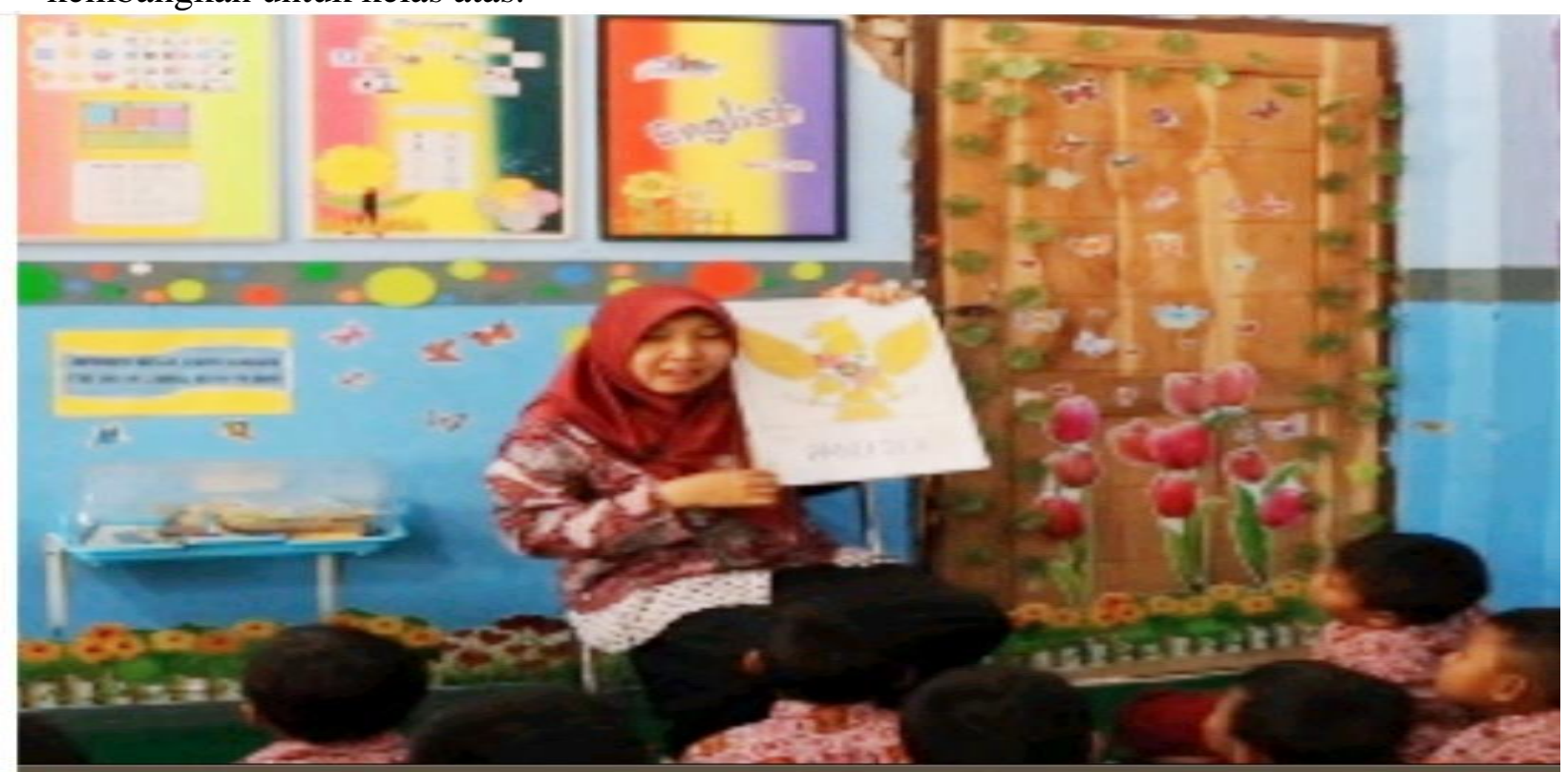

Gambar 5. Proses Pembelajaran dengan bigbook.

Berikut ini perubahan positif media pembelajaran bigbook:

\begin{tabular}{|l|l|}
\hline \multicolumn{1}{|c|}{ Sebelum } & \multicolumn{1}{c|}{ Sesudah } \\
\hline a. $\begin{array}{l}\text { Siswa sulit membaca pemahaman } \\
\text { (memahami isi teks) }\end{array}$ & a. $\begin{array}{l}\text { Siswa mudah membaca pemahaman } \\
\text { (memahami isi teks) }\end{array}$ \\
$\begin{array}{l}\text { b. } \begin{array}{l}\text { Siswa tidak fokus dalam kegiatan } \\
\text { membaca bersama karen tanpa adanya } \\
\text { media. }\end{array} \\
\text { c. Guru kurang kreatif membuat media } \\
\text { baca. }\end{array}$ & b. $\begin{array}{l}\text { Siswa fokus dalam kegiatan membaca } \\
\text { karena ada media baca yang berukuran } \\
\text { besar, gambar besar, dan tulisan besar. }\end{array}$ \\
\hline
\end{tabular}

\section{Tabel Interaktif Berupa Bintang Baca/Bintang Literasi.}

Interaktif adalah hal yang terkait dengan komunikasi dua arah/suatu hal bersifat saling melakukan aksi, saling aktif dan saling berhubungan serta mempunyai timbal balik antara satu dengan lainnya (Warsita:2008). 
Bintang baca adalah Tabel Interaktif kelas yang berisi rekapan jurnal baca/jurnal literasi, yang bertujuan untuk memberikan motivasi baca pada siswa. Siswa mendapatkan motivasi untuk dapatnya membaca buku sebanyak-banyaknya dengan harapan mendapatkan bintang baca. Bintang baca adalah rekapan dari jurnal baca/jurnal literasi.

Bintang baca dibuat bervariasi, ada yang berbentuk tabel ataupun pohon prestasi dsb. Bintang baca dipajang pada tempat yang mudah dilihat siswa pada dinding kelas. Perubahan minat baca yang sungguh luar biasa.

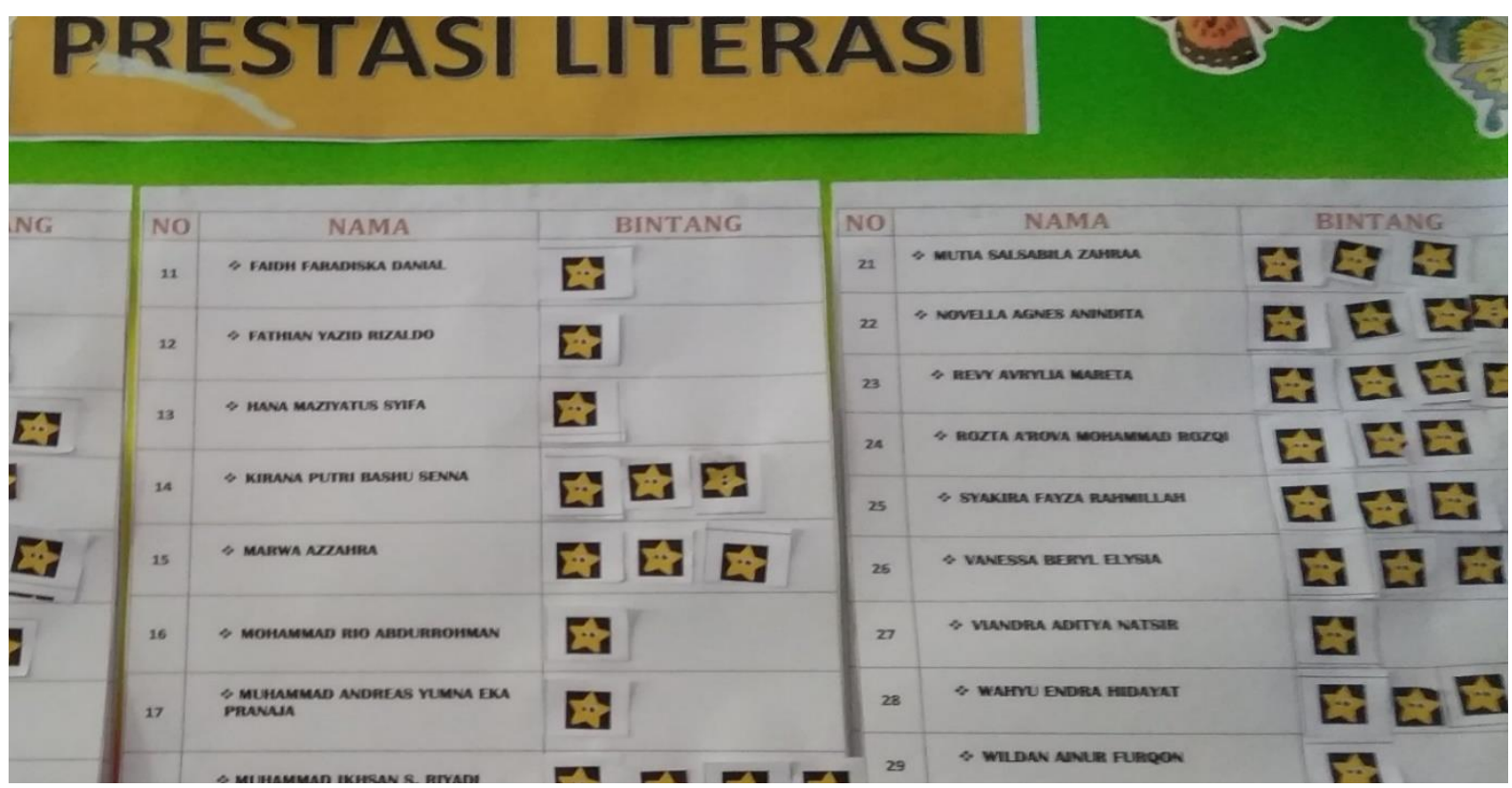

Gambar 6. Contoh Bintang Baca/Literasi Baca

Berikut ini perubahan positif adanya bintang baca/literasi baca:

\begin{tabular}{|l|ll|}
\hline \multicolumn{1}{|c|}{ Sebelum } & \multicolumn{1}{|c|}{ Sesudah } \\
\hline a. $\begin{array}{l}\text { Siswa tidak termotivasi untuk membaca } \\
\text { karena tidak ada reward/stimulus. }\end{array}$ & a. $\begin{array}{l}\text { Siswa berlomba-lomba banyak membaca, } \\
\text { untuk mendapatkan banyak bintang. }\end{array}$ \\
b. Siswa merasa bosan membaca. & b. $\begin{array}{l}\text { Siswa merasa senang karena mendapat } \\
\text { penghargaan membaca. }\end{array}$ \\
\hline
\end{tabular}

\section{Minat Baca Siswa.}

Hernowo (2002), mendefinisikan minat baca sebagai suatu perhatian yang kuat dan mendalam disertai dengan perasaan senang terhadap kegiatan membaca sehingga mengarahkan anak untuk membaca dengan kemauanya sendiri. Aspek minat baca meliputi kesenangan membaca, kesadaran akan manfaat membaca, frekuensi membaca, dan jumlah buku bacaan yang pernah dibaca oleh anak.Sedangkan Santoso (2011), mengartikan minat membaca adalah sikap positif dan adanya rasa keterikatan dalam diri anak terhadap aktivitas membaca dan tertarik terhadap buku bacaan. Kemudian selanjutnya Fauzi Adzim (2004), minat baca didefinisikan sebagai tingkat kesenangan yang kuat (excitement) dalam melakukan kegiatan membaca yang dipilihnya, karena kegitan tersebut menyenangkan dan memberi nilai kepada pelakunya.

Berdasarkan pendapat-pendapat di atas, maka peneliti menyimpulkan bahwa minat baca ialah kekuatan yang mendorong seseorang untuk memperhatikan, merasa tertarik dan 
senang terhadap aktivitas membaca sehingga seseorang malakukan aktivitas membaca dengan kemauanya sendiri

Menumbuhkan minat baca pada seseorang tidak bisa terjadi begitu saja, namun ada berbagai upaya serta faktor-faktor pendukung yang dapat memicu tumbuhnya minat baca. Adapun faktor pendukung tumbuhnya minat baca antara lain.

1) Rasa ingin tahu yang tinggi atas fakta, teori, prinsip, pengetahuan dan informasi.

2) Keadaan lingkungan fisik yang memadahi, dalam arti tersedianya bahan bacaan yang menarik, berkualitas, dan beragam.

3) Keadaan lingkungan sosial yang kondusif, maksudnya adanya iklim yang dapat dimanfaatkan untuk membaca.

4) Rasa haus informasi, rasa ingin tahu, terutama yang 63ctual

5) Berprinsip hidup bahwa membaca merupakan kebutuhan rohani

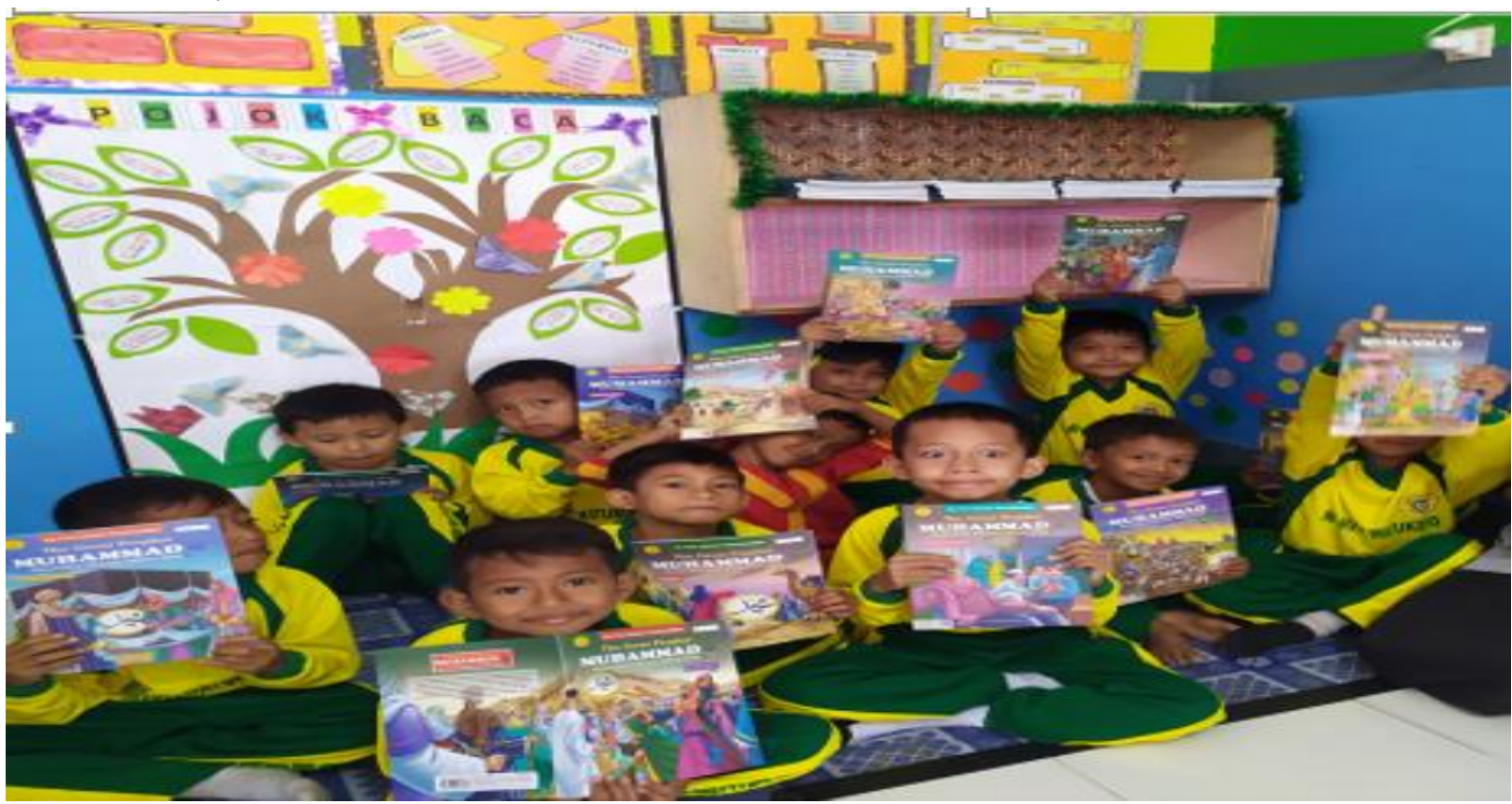

Gambar 7. Kegiatan membaca di pojok baca kelas.

Berikut ini perubahan positif minat baca siswa:

\begin{tabular}{|l|rl|}
\hline \multicolumn{1}{|c|}{ Sebelum } & \multicolumn{1}{c|}{ Sesudah } \\
\hline a. & Minat baca siswa rendah, terlihat dari \\
sepinya aktivitas anak-anak untuk & a. & $\begin{array}{l}\text { Minat baca siswa meningkat, terlihat } \\
\text { dari antusiasnya siswa membaca di }\end{array}$ \\
membaca di perpustakaan atau kelas. & pojok baca ataupun saat bus perpusda \\
b. Siswa tidak suka membeli buku cerita & hadir kesekolah. \\
atau bacaan. & b. $\begin{array}{l}\text { Siswa suka membeli buku cerita atau } \\
\text { bacaan. Beberapa siswa aktif } \\
\end{array}$ & mengikuti kelas menulis buku dan \\
& beprestasi dalam lomba literasi baca, \\
& seperti baca puisi tingkat provinsi.
\end{tabular}




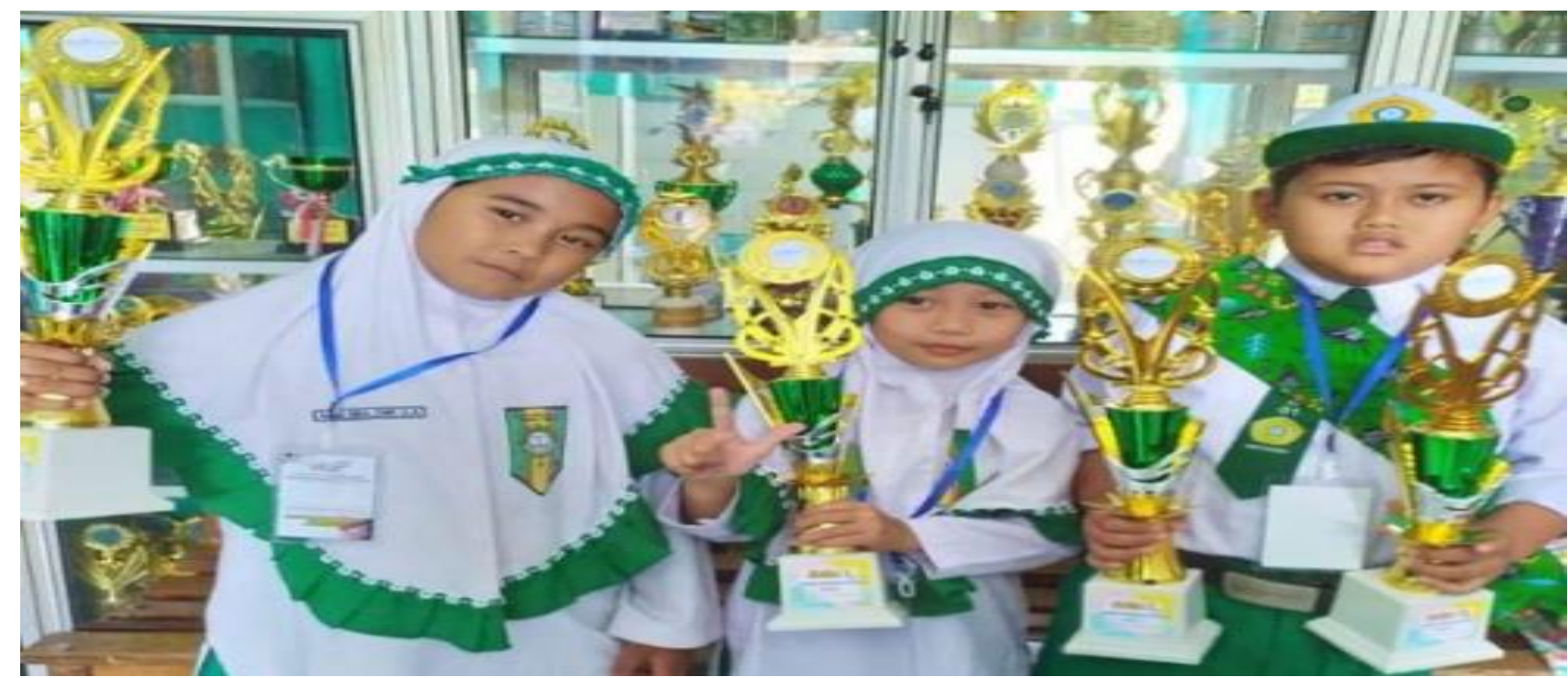

Gambar 8. Juara baca puisi tingkat provinsi Jawa Timur.

\section{KESIMPULAN}

Kesimpulan yang dapat diambil dari penulisan best practice ini adalah : 1) Pengembangan potensi anak dapat dilakukan diantaranya dengan mengembangkan budaya membaca. 2) L ingkungan sekolah yang literat, indah, nyaman dan ramah, serta perlengkapan/media yang menarik, aktivitas yang menyenangkan memotivasi membaca siswa.3) Lingkungan sekolah dan kelas yang kaya dengan media kebahasaan dan cetakan serta sudut baca, media pembelajaran kreatif inovatif literasi dengan tutup botol, bigbook, dan tabel interaktif berupa jurnal literasi dan bintang baca mampu menumbuhkan minat baca. 4) Media kreatif, inovatif, fleksibel, mudah dan sederhana dengan media pembelajaran tutup botol dan big book dapat memberikan inovasi kegiatan baca yang menyenangkan/menghibur/tidak membosankan dan kreatif. 5). Tabel interaktif berupa bintang baca/bintang literasi yang variatif mampu memotivasi siswa rajin dan terbiasa membaca. 6) Terbiasa membaca di usia dini diharapkan menjadi terbiasa membaca saat dewasa.

\section{DAFTAR PUSTAKA}

Adhim, Moh. Fauzi. (2004). Membuat Anak Gila Membaca. Bandung: Mizania, 2004.

Astuti, Dwi Puji. (2013). Minat Baca Penentu Kualitas Bangsa. Jurnal Pendidikan, Vol 2, No 3.

Hernowo. (2002). Mengingat Makna: Kiat-Kiat Ampuh untuk Melejitkan Kemauan Plus Kemampuan Membaca dan Menulis Buku. Bandung: Penerbit Kaifa

Mildred, Dawson dan Henry A. Bamman. (1960). Fundamentals of Basic Reading Instruction. New York: Longmans, Green and Co

Modul Literasi 1 dan Literasi 2 program INOVASI (kerjasama DFAT dan Pemerintah Indonesia)

Santoso, Hari. (2011). Membangun Minat Baca Anak Usia Dini Melalui Penyediaan Buku Bergambar. Jurnal Pustakwan, Vol 2, No 2.

Tim Applied Approach Peningkatan Rancangan Pengajaran Universitas Brawijaya (1993). http://hermawan12345.blogspot.com/2016/05/kelas-yang-literat.html?m=1 